\title{
The Effect of the Intervening Variables Age, Sex and Overweight on the Intravenous Glucose Tolerance Test ,
}

\author{
By J. D. Kruse-Jarres and J. WERnER \\ Clinical Chemistry Laboratory of the Surgical Clinic, University of Freiburg and Faculty of Social Sciences, \\ University of Mannbeim
}

(Eingegangen am 15. Juni/12. November 1972)

The values for $k_{G}$ of the intravenous glucose tolerance test on 192 metabolically healthy as well as diabetic test persons were subjected to a three-dimensional variance analysis in order to examine the dependence of the glucose tolerance on age, sex and overweight. A dependence on overweight and sex could not be detected, whereas a significant fall of the values for $k_{G}$ with age can be observed at the $1 \%$ niveau. This dependence, however, is probably not entirely accounted for by age per se, but rather by concomitant variables connected with age. In view of the multidimensionality of the glucose tolerance variable, the authors consider it too early at present to establish appropriate age-dependent "normal ranges".

Die $k_{G}$-Werte des intravenösen Glucose-Toleranztest von 192 stoffwechselgesunden und diabetischen Probanden wurden zur Prüfung der Abhängigkeit der Glucosetoleranz von Alter, Geschlecht und Ubergewicht einer dreidimensionalen Varianzanalyse unterzogen. Während die Geschlechtsverteilung an der Grenze zur Signifikanz liegt, konnte eine Abhängigkeit vom Übergewicht nicht festgestellt werden. Hingegen' żeigt sich auf dem $1 \%$-Niveau ein signifikanter Abfall der $\mathrm{k}_{\mathrm{G}}$-Werte mit dem Alter.

Diese Abhängigkeit ist wahrscheinlich jedoch nicht vollständig durch das Alter per se, eher durch die Summe nicht direkt altersbedingter interrenierender Variabler erklärbar. Aufgrund der Multidimensionalität der Glucosetoleranz erscheint es den Verfassern zur Zeit verfrüht, entsprechende altersbedingte „Normbereiche“ anzugeben.

In a study of the intravenous glucose tolerance test published earlier, we placed the normal range of the glucose assimilation coefficient $\left(\mathrm{k}_{\mathrm{G}}\right)$ at $1.0-2.5$ (1). This normal range was evaluated by taking into consideration a number of factors, but not age, sex and overweight. The emphasis lay mainly on the dependence of dose on body weight.

Lundbaek (2), Bogorus (3), Kienholz (4), and very recently, LAZARovici (5), WosEgIEN (6) and KNICK (7) were able to find statistically significant age-dependent differences in the oral glucose tolerance test in the sense that the tolerance value diminished with age. With regard to the intravenous glucose tolerance test, Schilling (8) found no age-dependent tolerance decrease in normals, but a clear decrease in adipose individuals. Age and body weight therefore appear to have an effect on the tolerance niveau of glucose.

The effect of these two intervening variables on the intravenous glucose tolerance test has also been investigated in the present study. In addition, the variable of sex has been taken into consideration, since it might also have an influence on the tolerance value.

\section{Method:}

From the clientel of the Institute of Clinical Chemistry of the Mannheim Municipal Hospital during the period of 1969 to 1971, two groups of patients were selected, which may be described as follows: The test group consisted of 100 males and 92 females, of whom 143 were non-diabetic persons, with a normal metabolism as far as could be ascertained, and 49 diabetics. Thus the intravenous glucose tolerance test using $0.33 \mathrm{~g}$ glucose per $\mathrm{kg}$ body weight was carried out on 192 test persons. The continuous in vivo analysis of blood glucose is described elsewhere (9). $\mathbf{k}_{G-\text { values }}$ were determined for the test persons relative to the three variables under consideration. According to the findings mentioned above, it is to be expected that, for instance, older and overweight persons would have a lower tolerance value. For the statistical analysis of this question, a three-dimensional variance analysis $(10)$ is available, which uses the variables of age, overweight in percentage of deriation from the ideal weight ${ }^{1}$ ), and sex. For purposes of variance analysis, the random sample of 192 test persons is thus divided into $4 \cdot 4 \cdot 2$ groups (cf. Tab. 1, 2: data cell frequencies of the analysis of variance design) and the extent to which the mean values of these groups are statistically different is investigated.

Tab. 1

Male probands; overweight in percentage of deviation from the ideal weight: data cell frequencies of the analysis of variance design $\mathrm{N}=$ number of probands, $M=$ mean, $S D=$ standard deviation

\begin{tabular}{llllll}
\hline $\begin{array}{c}\text { Age } \\
\text { (years) }\end{array}$ & $<1 \%$ & $1-10 \%$ & $11-20 \%$ & $>21 \%$ \\
\hline & & & & \multicolumn{3}{c}{ Weight } \\
\hline $0-25$ & N & 12 & 6 & 3 & 3 \\
& $M$ & 1.337 & 1.523 & 1.533 & 1.103 \\
& SD & 0.608 & 0.225 & 1.427 & 0.503 \\
\hline \multirow{2}{*}{$26-40$} & N & 3 & 8 & 2 & 10 \\
& $M$ & 2.053 & 1.392 & 1.485 & 1.370 \\
& SD & 0.671 & 0.427 & 0.290 & 0.432 \\
\hline \multirow{2}{*}{$41-55$} & N & 2 & 6 & 4 & 12 \\
& $M$ & 1.370 & 1.373 & 0.907 & 0.996 \\
& SD & 0.424 & 0.433 & 0.259 & 0.477 \\
\hline \multirow{3}{*}{$>55$} & N & 4 & 4 & 6 & 15 \\
& $M$ & 1.105 & 0.672 & 0.805 & 0.880 \\
& SD & 0.455 & 0.332 & 0.433 & 0.495 \\
\hline
\end{tabular}

1) Weight with the highest life expectancy (According to Statist. . Bull. Metrop. Life Insur. Co., 40, 11 (1959)). 
Tab. 2

Female probands, overweight in percentage of deviation from the ideal weight: data cell frequencies of the analysis of variance design $\mathrm{N}=$ number of probands, $M=$ mean, $S D=$ standard deviation

\begin{tabular}{|c|c|c|c|c|}
\hline \multirow[b]{2}{*}{$\begin{array}{c}\text { Age } \\
\text { (years) }\end{array}$} & \multicolumn{4}{|c|}{ Weight } \\
\hline & $<1 \%$ & $1-10 \%$ & $11-20 \%$ & $>21 \%$ \\
\hline $0-25$ & $\begin{array}{cc}\mathrm{N} & 13 \\
\mathrm{M} & 1.587 \\
\mathrm{SD} & 0.472\end{array}$ & $\begin{array}{l}1 \\
1.831 \\
0.638\end{array}$ & $\begin{array}{l}1 \\
1.670\end{array}$ & $\begin{array}{l}3 \\
2.113 \\
0.251\end{array}$ \\
\hline $25-40$ & $\begin{array}{cc}\mathrm{N} & 6 \\
\mathrm{M} & 1.267 \\
\mathrm{SD} & 0.530\end{array}$ & $\begin{array}{l}7 \\
1.409 \\
0.555\end{array}$ & $\begin{array}{l}7 \\
1.584 \\
0.448\end{array}$ & $\begin{array}{l}5 \\
1.256 \\
0.443\end{array}$ \\
\hline $41-55$ & $\begin{array}{rl}\mathrm{N} & 2 \\
\mathrm{M} & 1.520 \\
\mathrm{SD} & 0.580\end{array}$ & $\begin{array}{l}3 \\
0.840 \\
0.374\end{array}$ & $\begin{array}{l}3 \\
1.407 \\
0.320\end{array}$ & $\begin{array}{l}13 \\
1.430 \\
0.407\end{array}$ \\
\hline$>55$ & $\begin{array}{rl}N & 5 \\
M & 1.106 \\
\text { SD } & 0.185\end{array}$ & $\begin{array}{l}5 \\
1.048 \\
0.485\end{array}$ & $\begin{array}{l}8 \\
1.077 \\
0.830\end{array}$ & $\begin{array}{l}3 \\
1.097 \\
0.500\end{array}$ \\
\hline
\end{tabular}

The expansions of the levels of the first two factors were performed approximately in a few steps, since the number of test persons is small in the statistical sense. The following age groups were selected : $0-25,26-40,41-55$ and 56 years and above. The variable overweight was registered under the following four categories: $0 \%$ to less than $1 \%, 1 \%$ to $10 \%, 11 \%$ to $20 \%$ and $21 \%$ and above.

\section{Results}

The results of the variance analysis are given in Table 3 . It is evident that the factor age is significant at the $1 \%$ confidence level $i$. e. that the mean values for $k_{G}$ prove to be different at the different age levels and that, as can be seen from the cell means, it decreases with age. The differences regarding sex just lie at the significance limit of $1 \%$ niveau (the exact error probability of $\mathrm{p}=.018$ is greater than .01 and therefore not significant at the $1 \%$ niveau). The interesting fact is that we could find no differences in the values for $k_{G}$ related to overweight and that no interactions are of statistical significance, i. e., for instance, applied to age and overweight, the values for $k_{G}$ were strictly additive (linear and not multilinear) and thereby contradict the results obtained by ScHILling (8), viz. that a clear deterioration of tolerance appears with age in adipose patients and none in normal weight individuals.

As revealed by the description of our random sample of test persons, our collection of patients contained individuals with normal metabolism as well as cases of varying degrees of diabetes. It is safe to assume that the course of glucose tolerance with respect to the three factors under investigation would be different in the case of test persons with metabolic disease from that in healthy individuals.

We therefore introduced the variable, healthy-diseased, as a co-variable into the above analysis of variance, thereby eliminating the effect of the variable, healthydiseased, from its three-dimensional AV-design.

After elimination of the effect of the variable, healthydiseased, different mean values for $\mathrm{k}_{\mathrm{G}}(\alpha<0.1)$ are only obtained for the age factor. (The regression of the
Tab. 3

Analysis of variance: three factors age, sex and overweight This analysis was calculated using the MONOVA-program of the Rechenzentrum Mannheim

SS = sums of squares, DF = Degrees of freedom, $M S=$ Mean square (SS/DF), F = Result of analysis of variance (= Fisher-Test), $p=$ Result of analysis of significance (= STUDENTTest)

\begin{tabular}{lrrrrr}
\hline \multicolumn{1}{c}{ Source } & SS & DF & MS & F & $\begin{array}{c}\text { Smaller } \\
\text { than } \\
\text { p }\end{array}$ \\
\hline Within the groups & 42.075 & 160 & 0.263 & & \\
\% overweight & 0.099 & 3 & 0.033 & 0.126 & 0.945 \\
Sex & 1.492 & 1 & 1.492 & 5.672 & 0.018 \\
Age & 10.312 & 3 & 3.437 & 13.071 & 0.001 \\
Age $\times$ \% overweight & 1.135 & 9 & 0.126 & 0.480 & 0.887 \\
Age $\times$ sex & 1.676 & 3 & 0.559 & 2.124 & 0.099 \\
$\%$ overweight $\times$ sex & 1.342 & 3 & 0.447 & 1.701 & 0.169 \\
Age $\times$ \% overweight & & & & & \\
$\quad \times$ sex & 2.151 & 9 & 0.239 & 0.909 & 0.519 \\
\hline
\end{tabular}

Tab. 4

Analysis of variance: three factors age, sex and overweight. Covariable: healthy-diseased

This analysis was calculated using the MONOVA-program of the Rechenzentrum Mannheim

$S S=$ sums of squares, $D F=$ Degrees of freedom, $M S=$ Mean square $(S S / D F), F=$ Result of analysis of variance ( = FisheR-Test), $p=$ Result of analysis of significance (= STUDENT-Test)

\begin{tabular}{lrrrrr}
\hline \multicolumn{1}{c}{ Source } & SS & DF & MS & F & $\begin{array}{c}\text { Smaller } \\
\text { than }\end{array}$ \\
\hline Within the groups & 25.577 & 159 & 0.161 & & \\
Regression & 16.495 & 1 & 16.498 & 102.562 & 0.001 \\
\% overweight & 0.142 & 3 & 0.047 & 0.295 & 0.829 \\
Sex & 0.051 & 1 & 0.051 & 0.317 & 0.575 \\
Age & 2.137 & 3 & 0.712 & 4.429 & 0.005 \\
Age $\times$ \% overweight & 1.111 & 9 & 0.123 & 0.767 & 0.647 \\
Age $\times$ sex & 0.526 & 3 & 0.175 & 1.090 & 0.355 \\
\% overweight $\times$ sex & 0.759 & 3 & 0.253 & 1.574 & 0.198 \\
Age $\times \%$ overweight & & & & & \\
$\quad \times$ sex & 1.112 & 9 & 0.768 & 0.768 & 0.646 \\
\hline
\end{tabular}

co-variable, healthy-diseased, on the values of $k_{G}$ is trivially significant, since the test persons are not in the last place classified on basis of this value into metabolically healthy and metabolically diseased.)

No less important than the ascertainment that age differences are valid for glucose tolerance is the investigation of the corresponding trend of values for intravenous glucose tolerance test over the age groups. The determination of the function of this trend is important, for example, for the derivation of agedependent correction formulas. Since nothing is a priori known about the nature of the functional relation between the variables, age and glucose tolerance, it is suitable to start from polynomial equations and then examine which function best fits to the data. The fitting of the polynomial curve was carried out seperately for metabolically diseased and metabolically healthy test persons: The metabolically diseased group shows no significant trend at all, whereas for the metabolically healthy group the polynomials are satisfactorily significant up to third degree ${ }^{2}$ ).

2) The polynomial curve fitting was carried out using the BMD $05 R$ program of the Rechenzentrum Mannheim. 


\section{Discussion}

A determination of polynomials reliable in the statistical sense could not be carried out because of the low number of test persons especially in the metabolically diseased group $(\mathrm{N}=50)$. The results of the polynomial fitting are only of an exploratory character and will be reevaluated by the authors when larger numbers of test persons are available: In the metabolically healthy group, the mathematical representation of the relationship between age and values for $k_{G}$ cannot be adequately characterized by a simple linear regression, for it contains square and cubic components in addition. In the metabolically diseased group, however, not even the linear regression is stastistically significant (Fig. 1: the linear function is parallel to the $\mathrm{x}$-axis). This result appears to be plausible and would mean that the values for $k_{G}$ do not change with age in the case of metabolically diseased patients.

The interpretation of the results of the group of diabetics is obvious; that of the metabolically healthy test persons, on the other hand, is not as unequivocal as it might appear at the first sight: The deterioration of tolerance due to age is frequently accounted for by making corrections on the basis of regressively agedependent "normal ranges". In view of the evaluations

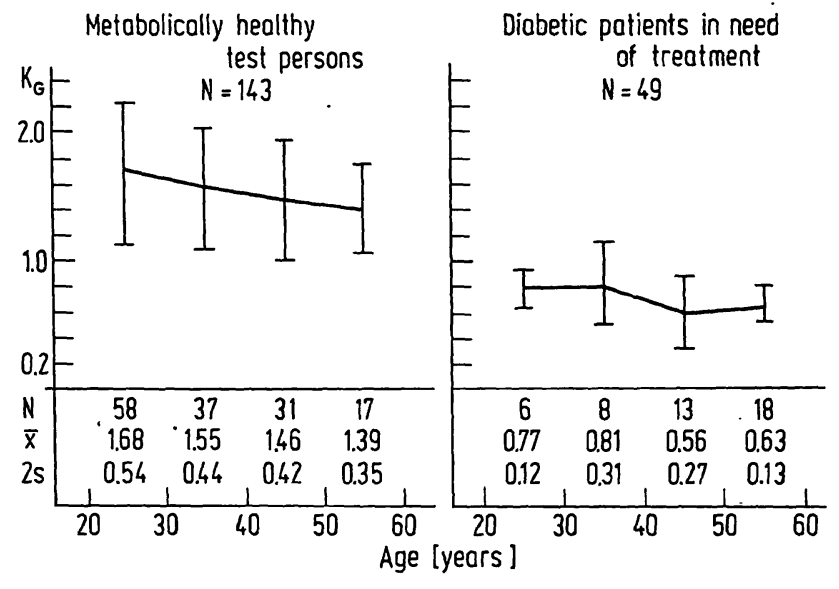

Fig. 1

Age-dependence of the mean assimilation coefficients in the intravenous glucose tolerance test in the case of metabolically healthy persons (left) and diabetic patients (right) of our data, a normal range of $1.68 \pm 0.53$ up to the age of 25 years and one of $1.39 \pm 0.35$ at ages of 56 years and above would have to be assumed. On the other hand, Dieterle (11) found that the glucose tolerance in the various decades of life, after elimination of all risk factors (such as diseases of the liver, diseases of the vessels, essential hypertension, chronic inflammations of the pancreas, repeated stress situations etc.), is identical up to the 60th year of age.

Attention has repeatedly been drawn to the differences between the chronological or calendar age on the one hand and the biological or functional age on the other hand (12). The former is orientated on the continuous physical time; the latter is indeed basically related to the former, but can, however, deviate from it considerably in individual cases. These deviations are yielded by the difference between the sums of the ageindependent and the age-specific risk factors. It is, however, not yet possible to estimate the magnitude of the effects and the affiliation of the individual variables. In particular, it is not conclusively known whether the dependence of glucose tolerance on age can be entirely explained by means of the risk factors mentioned or whether there are age-specific variations in the metabolism of glucose in addition to those caused by the risk factors.

In view of the multifactoral causality of the glucose tolerance and the related aetiological obșcurity of the effects of "age-dependent variables", it appears to us to be neither necessary nor helpful for the present pragmatical handling of the intravenous glucose tolerance test as an indicator of diabetes to cite a "normal range for age". This is often done and leads to a judgement on basis of "normal ranges" recruited from the statistical mean values of effects that are often not valid for the individual case. Furthermore, we do not consider it justified to view the incorporation of such staggered results into the clinical diagnosis as being "revealing and, in the younger and middle years of age, meaningful indeed in general" (12). As long as the clarification of all age-specific risk factors is incomplete, this is equivalent to trying to improve the quality of a test without checking for validity.

\section{References}

1. Kruse-Jarres, J. D., Hilpert, C., Grohmann, K. \& KlingMülleR, V. (1971), Deut. Med. Wochenschr. 96, 1424-1430. 2. Lundbaek, K. (1964), Z. Med. Wiss. 6, 194-197. - 3. Bogorus, M. S. \& Gilbert, J. A. (1966), Can. Med. Ass. J. 94, 660. 4. Kienholz, M. (1967), Med. Welt 18, 2760. - 5. LazArovicr, A. M., Labram, C., Dalle, J. \& Lestradet, H. (1969), Presse Med. 77, 2143-2144. - 6. Wosegren, F. (1971), Deut. Med. Wochenschr. 96, 1697. - 7. KNICK, B. (1972), Med. Klin. 67, 34 - 35. - 8. Schilling, W. H., Oberdisse, K., Hüter, K.
A. \& Blank, H. (1965), Diabetologia 1, 187-194. - 9. KRUSEJARRES, J. D., REITER, J. \& KLINGMÜLLER, V. (1969), Klin. Wochenschr. 47, 462-469. - 10. WINER, B. J. (1962), Statistical Principles in Experimental Design, Mc Graw Hill, New York. - 11. Dieterle, P. (1971), Internist 12, 463-466. - 12: BöCher, R. (1971), Fortschr. Med. 89, 979-982. - 13. Franckson; J. R. M., Ooms, H. A., Bellens, R., Conrad, V. \& Bastente, P. A. (1972), Metab. Clin. Exp. 11, 482-500.

Priv. Doz. Dr. med. J. D. Kruse-Jarres

Klinisch-Chemisches Labor

Chirurgische Universitätsklinik

D 78 Freiburg i. Br.

Hugstetter Straße 55 